\title{
Antioxydant Activity of Some Algerian Olive Oil Samples in the Eastern and Center of Algeria
}

\author{
Metlef Sarra ${ }^{1}$, Dilmi-Bouras Abdelkader ${ }^{2}$, Zidane Azdinia ${ }^{3}$ and Benali Mohammed ${ }^{4}$ \\ 1. Laboratory of Natural Bio-Ressources, Department of Biology, Faculty of Sciences, University Djillali Liabès of Sidi Belabesse, \\ Sidi Belabesse 022002, Algeria \\ 2. Laboratory of Natural Bio-Ressources, Department of Human Nutrition and Food Sciences, Faculty of Nature and Life Sciences, \\ University Hassiba Benbouali of Chlef, Chlef 02000, Algeria \\ 3. Laboratory of Natural Bio-Ressources, Department of Biology, Faculty of Nature and Life Sciences, University Hassiba Benbouali \\ of Chlef, Chlef 02000, Algeria \\ 4. Laboratory of Biotoxicology, Department of Biology, Faculty of Sciences, University Djillali Liabès of Sidi Belabesse, Sidi \\ Belabesse 022002, Algeria
}

\begin{abstract}
This study aimed to evaluate the antioxidant activity of five Algerian olive oil samples from Chlef, Jijel, Tissemsilt, Bejaia and Tizi Ouzou regions. Thus the following results were found physicochemical caracterisation revealed that the samples are conform to standards prescribed by IOC (2013) as they are type-oleic and linoleic varies between virgin and extra virgin Chlef, Djijel and Bejaia oils are richer in carotenoids than those of Tizi Ouzou and Tissemsilt. Chlef and Tissemsilt oils are richer in phenolic compounds than other oils and have revealed very important antioxidant activity and the largest inhibitory power of peroxidation.
\end{abstract}

Key words: Algeria, antioxidant activity, olive oil, phenolic extracts, standards.

\section{Introduction}

Olive oil is obtained by natural extraction from Olea europaea L. in except of oil obtained by solvent or by rectification process and any mixture with oils of other nature $[1,2]$. It is one of the oldest vegetable oils and the only one which can be consumed in its raw form without prior treatment [3]. It represents a typical source of mediterranean diet lipids with a content of $65 \%$ to $80 \%$ of monounsaturated fatty acids, represented mainly by oleic acid, $15 \%$ of unsaturated fatty acids and $10 \%$ of polyunsaturated fatty acids represented by dominant linoleic acid (Omega-6) and traces of alpha-linoleic acid (Omega-3) whose consumption has been associated with a limited incidence of cardiovascular disease, neurological disorders, and colon cancer [4]. Olive oil also contains

Corresponding author: Metlef Sarra, Ph.D., research fields: biology. minor compounds which are phenols, tocopherols, carotenoids and sterols considered as highly bioavailable molecules and bioactive hatred, giving many benefits on human health. As long as they are very important antioxidants, they fight the free radicals with the deleterious effects: aggressions of the cells, modification of the DNA, oxidation of the lipids [5]. Olive oil is endowed with several biological activities (antioxidant and antimicrobial), but it is the presence of phenolic compounds and other antioxidants which give the oil a high stability against oxidation [6]. Algeria is ranked among the top ten producing countries ranking (9th), with a world production of 1\% [7], more than 62 thousand tons of oil in this production is provided by several regions (east, west, central and southern part in Algeria) [8], the composition and quality of olive oils are influenced by several factors such as cultivation techniques, the knowledge of the producers and the variety of the olive, which explain the differences in the 
biological activities between them [9, 10].

In this context, our study aims to extract the polyphenols of olive oil from the east and center of Algeria and evaluate their antioxidant activity.

\section{Materials and Methods}

The study involved five original Algerian olive oil samples collected from the most predominant areas in olive production located in the east and center parts of Algeria: Bejaia, Chlef, Jijel, Tizi Ouzou and Tissemsilt (Fig. 1). They were obtained from conventional extraction units located in various regions and using olive by pressure extraction technique without any addition or subtraction.

\subsection{Determination of Carotenoids Content}

Determining the carotenoids content in our samples was carried out according to the procedure described by Ref. [11]: Seven point five grams of oil were introduced into a $25 \mathrm{~mL}$ volumetric flask which is subsequently filled up to the mark with cyclohexane, the absorbance of the solution of the fat obtained was measured against that of the solvent at $470 \mathrm{~nm}$. The carotenes content is determined by the following formula:

$$
\begin{gathered}
\text { Carotne }(\mathrm{ppm})= \\
(\mathrm{A} 470 \times 25 \times 10,000) /(2,000 \times 7.5)
\end{gathered}
$$

\subsection{Extraction of Total Polyphenols}

The extraction of total polyphenols in our oil samples was made following Refs. [12, 13] method Mix $20 \mathrm{IU}(0.2 \mathrm{~mL})$ of oil with $400 \mathrm{uL}(0.4 \mathrm{~mL})$ of a mixture of water/methanol (25/75). The mixture is vortexed for $1 \mathrm{~min}$ for the extraction of polyphenols in the methanolic medium adding $200 \mathrm{uL}(0.2 \mathrm{~mL})$ of dichloromethane. Centrifuge the mixture at 3,500 revolutions/min for 10 facilitate the collection of 200 $\mathrm{uL}(0.2 \mathrm{~mL})$ of supernatant methanol.

\subsection{Determination of Total Polyphenols by Colorimetry}

The determination of total polyphenols was made according to the method in Ref. [14]:

Adding $800 \mathrm{uL}(0.8 \mathrm{~mL})$ of Folin reagent diluted 10 times with phenolic extracts and allowing the mixture rested $2 \mathrm{~min}$ at room temperature before adding $1 \mathrm{~mL}$ of sodium carbonate $(75 \mathrm{~g} / \mathrm{L})$ heated the mixture for 15 min at $50{ }^{\circ} \mathrm{C}$ and analyzed at $760 \mathrm{~nm}$; external calibration was performed using gallic acid at different concentrations.

\subsection{Trapping Test Radical DPPH}

In this study we followed the procedure of Ref. [15] $50 \mathrm{~mL}$ of each extract and different dilutions, as well as standards (BHT and ascorbic acid at $10 \mathrm{mg} / \mathrm{mL}$, and

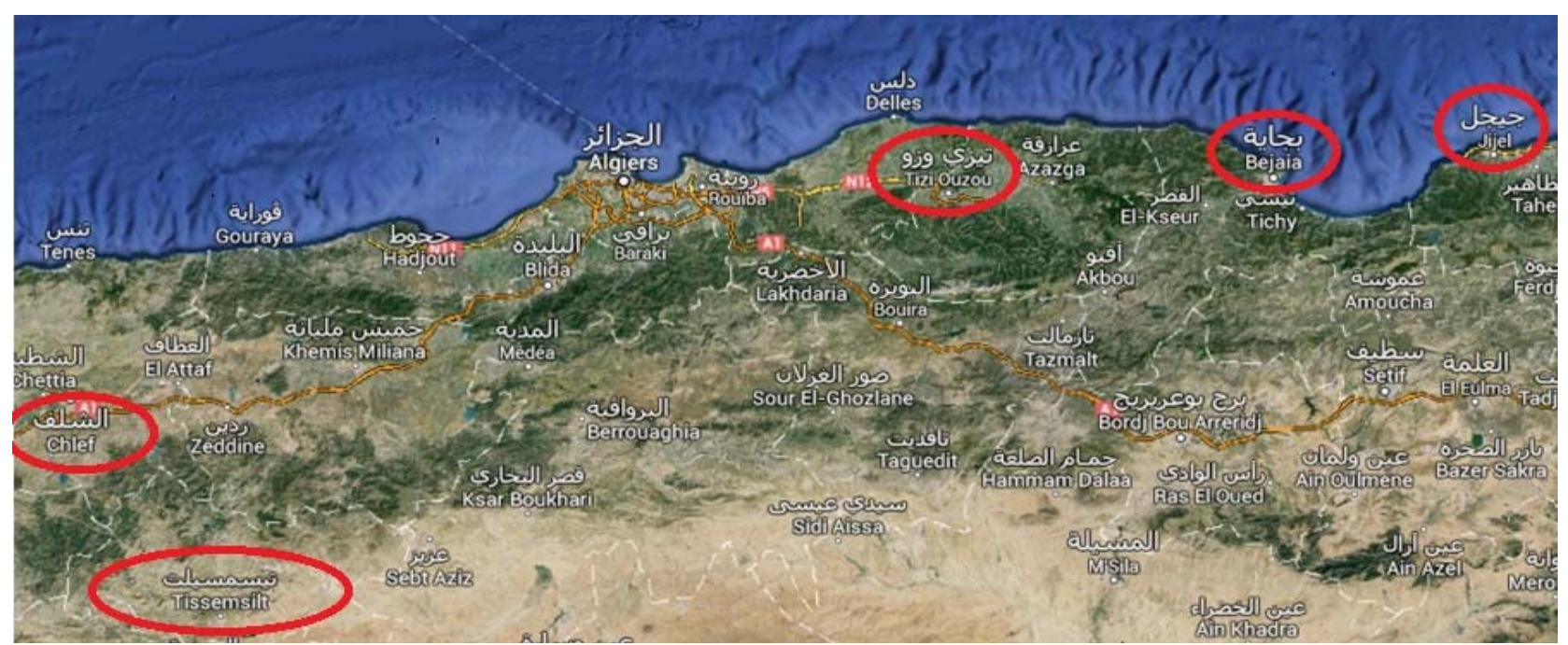

Fig. 1 Location of the olive oil samples areas. 
control) are added to a volume of $2.9 \mathrm{~mL}$ of a methanol solution of DPPH $\left(6,086 \times 10^{-5} \mathrm{~mol} / \mathrm{L}\right)$. This mixture was incubated 30 minutes, followed by measurement of absorbance at $517 \mathrm{~nm}$. The percentage of the anti-radical activity is estimated by the following formula:

$$
\% A A R=
$$

D.O contrôle - D.O échantillon/D.O contrôle $\times 100$ (2)

The completion of the kinetics of this activity was used to determine the concentrations IC50. IC50 corresponds to the value of $50 \%$ inhibition. The IC50 value is expressed in $\mathrm{g} / \mathrm{mL}$.

\section{Results and Discussion}

\subsection{Results of Carotenoids Assay}

The results showed that Chlef's, Jijel's and Bejaia's olive oils carotenoid composition are respectively $14.04 \mathrm{mg} / 100 \mathrm{~g}, 10.33 \mathrm{mg} / 100 \mathrm{~g}, 10.98 \mathrm{mg} / 100 \mathrm{~g}$, these values are very important comparing to those of Tizi Ouzou and Tissemsilt ones with 8.8 mg/100 g, 7.3 mg/100 mg respectively (Fig. 2).

The low carotenoid pigments in Tizi Ouzou and Tissemsilt oils may be accorded to the maturity of olives, the collection methods, the retrieval system, or the age of oil as is mentioned by Ref. [16].

According to Ref. [17] carotenes are natural chemical substances involved in the oxidation mechanisms of the oil, their presence in sufficient quantity in the oil makes it possible to delay the phenomena of photo oxidation and to preserve the quality parameters of the oil during storage, our results are consistent with those obtained for the Spanish Cornicabra variety, which has carotene levels ranging from 2 to $14 \mathrm{mg} / \mathrm{kg}$ [18].

\subsection{Results of Polyphenols Total Assay}

The results summarized in Fig. 3 indicated variability in the total polyphenol contents of the five samples showing that Chlef and Tissemsilt oils (172.91 and $199.974 \mathrm{mg}$ of caffeic acid/kg respectively) were the richest in these compounds compared to other samples as is showed in Fig. 3.

The amounts of phenols present in olive oils which have been reported in the literature are very variable. Refs. [12-19] lanced that the phenols content is 232 $\mathrm{mg} / \mathrm{kg}$ for extra virgin olive oils and $62 \mathrm{mg} / \mathrm{kg}$ for refined oil. Depending on the duration of grinding and contact with air, the oil is depleted of total polyphenols and o-diphenols responsible for the antioxidant activity, these relatively water-soluble compounds pass partially in the margins but generally the concentration of phenols in olive oil varies between $1 \mathrm{~g} / \mathrm{kg}$ and 800 $\mathrm{mg} / \mathrm{kg}[20,21]$.

The polyphenols pass into the oil during extraction. Ortho diphenols (such as hydroxytyrosol, caffeic acid and oleuropein) in olive oil are considered to be natural

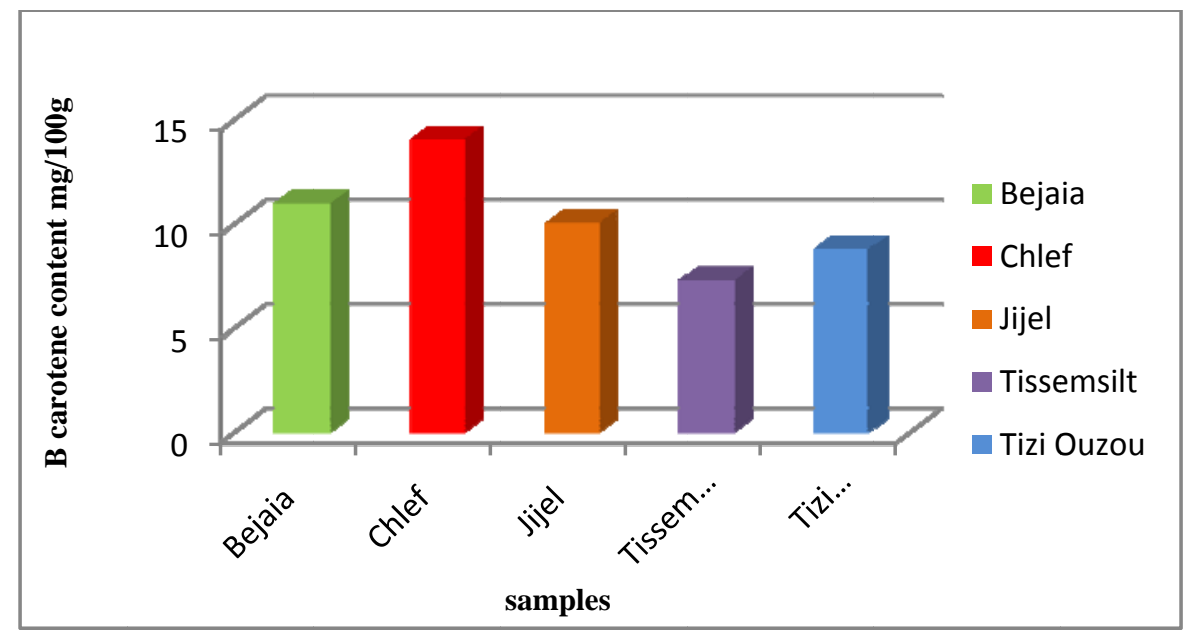

Fig. 2 Results of carotenoids assay in the five oil samples. 


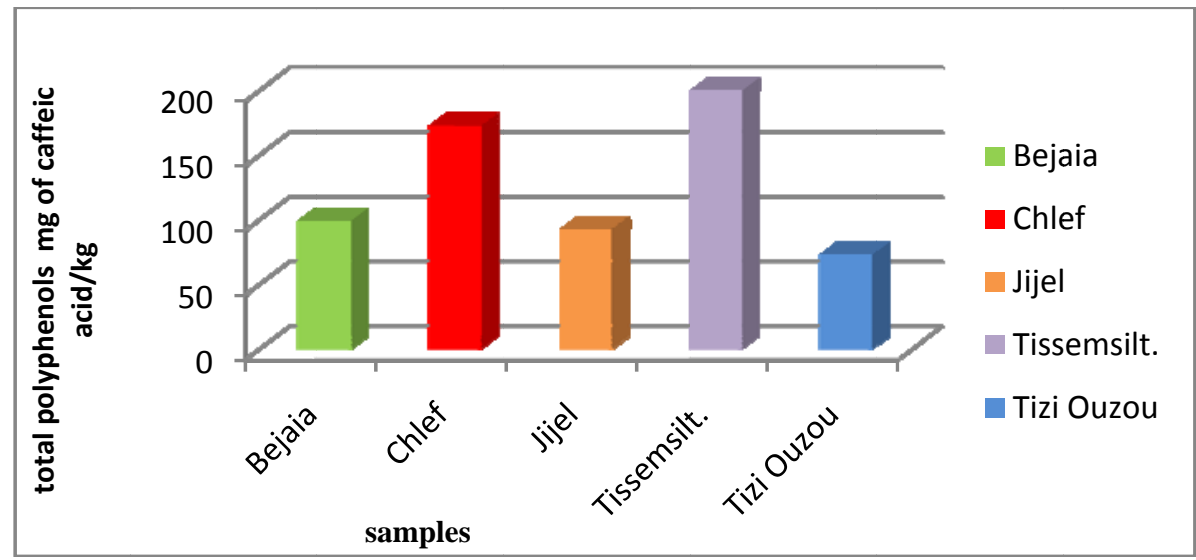

Fig. 3 Results of determination of phenolic compounds in olive oils samples.

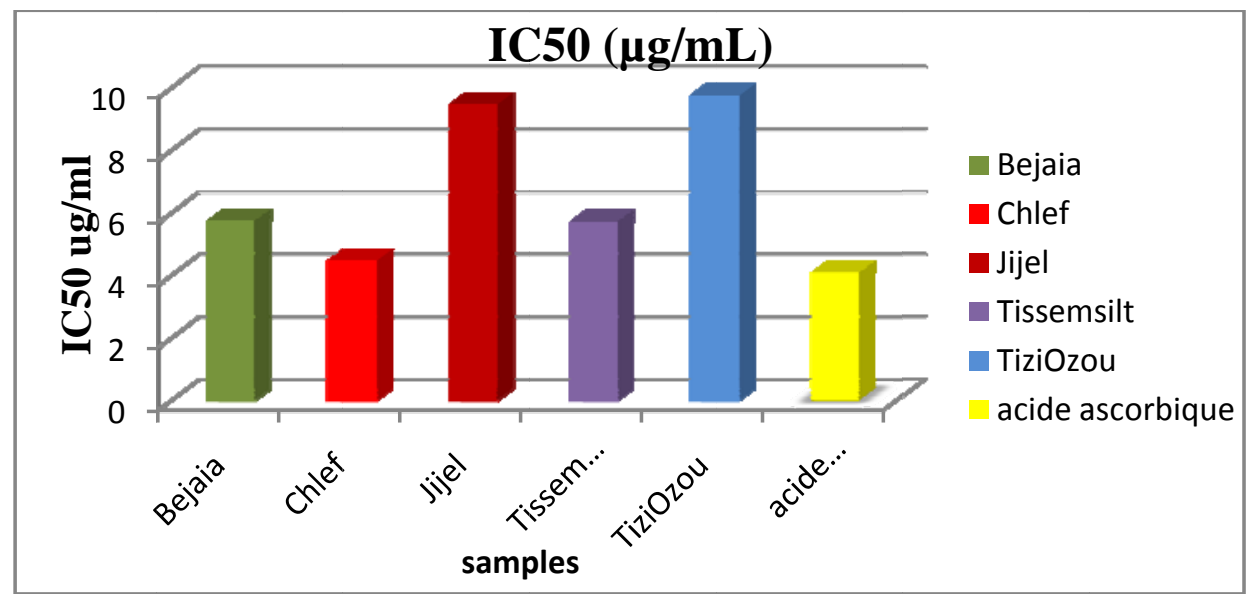

Fig. 4 Values of concentrations responsible in $50 \%$ inhibition of DPPH radical.

antioxidants that protect the oil against oxidation, giving it a better stability during storage, a bitter taste and a sensation of pungency [22, 23].

\subsection{Antioxidant Power of Phenolic Extracts of the Five Oil Samples}

The results of the radical scavenging DPPH through the determination of IC50 values for the five phenolic extracts of oils are presented in Fig. 4. These results demonstrated a significant potential, we noticed that Chlef and Tissemsilt oils have the most important activities with IC50 values of $3.67 \%$ and $5.74 \%$ respectively.

The activity of Bejaia and Jijel oils was always important with an IC50 of about 5.75, while those of Jijel and Tizi Ouzou were lowest compared to other samples (9.48 and 9.76\%).

In light of these results, we will deduce that Chlef,
Tissemsilt and Bejaia oils have the most significant radical scavenging activities, and this can be explained by their high phenolic content compared to other extracts.

Such variation in the antioxidant capacity of the polyphenol extracts of oils could be due to differences in the composition of the extracts as showed by Ref. [24], in particular the presence of some phenolic active compounds such as oleuropein, tyrosol (product of the hydrolysis of oleuropein) and hydroxytyrosol in oil and not in another as reported by Refs. [25, 26].

\section{Conclusions}

The chemical characterization of our samples has revealed that they met all the standards and allowed us to draw the following conclusions:

The important differences in the contein of samples with carotenoids were in Chlef, Djijel and Bejaia oils 
much richer in carotenoids than Tizi Ouzou and Tissemsilt ones.

Chlef and Tissemsilt samples were rich in phenolic compounds than other oils and possessed the most important antioxidant activity with IC50 values of 3.67 and 5.74 respectively.

Finally, we suggest increasing the number of samples to target other regions of Algeria and to characterize phenolic compounds of the various samples of oils using HPLS-MS/MS techniques.

\section{References}

[1] CEE. 2003. "Characteristics of Olive and Olive Pomace Oil and Their Analytical Methods, EEC Regulation 1989/2003." Official Journal of the European Communities 295: 57-66.

[2] Codex Alimentarius. 1989. “ Norme codex pour les huiles d'olive vierges et raffinées et pour l' huile de grignons d’olive raffinée.” Codex STAN 33-1981 (Rév. 1-1989).

[3] International Oleicol Council. 2013. T.15/NCn 9/Rev.6. "Commercial Norme Applicable to Olive Oil and Olive-Pomace Oils.”

[4] Garcia-Villalba, R., Carrasco-Poncorbo, A., Oliveras-Ferraros C., Vasquez-Martin A., Menéndez J. A., Segura-Carretero, A., and Fernandez-Gutiérrez, A. 2010. "Characterisation and Quantification of Phenolic Compounds of Extra-Virgin Olive Oils with Anticancer Properties by a Rapid LC-ESI-TOF MS Method.” Journal of Pharmaceutical and Biomedical Analysis 51 (2): 416-9.

[5] Abu-Reidah, M. I., Yasin, M., Urbani, S., Servili, M., and Montedoro, G. 2013. "Study and Characterization of Palestinian Monovarietal Nabali Virgin Olive Oils from Northern West Bank of Palestine.” Journal Food Research International 54 (2): 1959-64.

[6] Servili M., Selvaggini R., Taticchi A., Esposto S., and Montedoro G. 2003. "Volatile Compounds and Phenolic Composition of Virgin Olive Oil: Optimisation of Temperature and Time of Exposure of Olive Pastes to Air Contact during the Mechanical Extraction Process.” J. Agric. Food. Chem. 27: 7980-8.

[7] Barjol, J. L. 2014. “Olive Oil.” Rev: Ocl. 21 (5): D502.

[8] Pinatel, C., Petit, C., Ollivier, D., and Artaud, J. 2004. "Outil pour l'amélioration organoleptique des huiles d'olive vierges.” Oléagineux, Corps Gras, Lipides 11 (3): 217-22.

[9] Zhu, L. I., Li, X., Liu, Z., and Weber, P. 2010. "Hydroxyterosol Protects against Oxydative Damage by Simultaneous Activation of Mitochondrial Biogenesis and
Phase II Detoxifying Enzyme Systems in Retinal Pigment Epithelial Cells.” Journal of Nutritional Biochemistry 21: 1089-98.

[10] International Oleicol Council. 2015. COI/T.15/NCn 3/Rév.8.

[11] Mariod, A. A., and Ibrahimi, R. M. 2010. “Antioxydant Activities of Phenolic Rich Fraction Obtained of Black Monchema Ciliatum.” Food Chimistry 118: 120-7.

[12] Owen, R.W., Mier, W., Giacosa, A., Hull, W. E., and Bartch, H. 2000. "Phenolic Compounds and Squalene in Olive Oils: The Concentration and Antioxydant Potential of Total Phenols.” Food Chemistry Toxicol 38: 647-59.

[13] Abaza, L., Taamalli, A., Nsir, H., and Zrrouk, M. 2015. “Olive Tree (Olea europeae L.) Leaves: Importance and Advances in the Analysis of Phenolic Compounds." Antioxidants 4: 682-98.

[14] Folin, C. 1999. “Analysis of Total Phenols and Other Oxidation Substrates and Antioxidants by Means of Folin-Ciocalteu Reagent. Oxidants and Antioxidants Part A.” Methods in Enzymology 299: 152-78.

[15] Kartal, N., Sokmen, M., Tepe, B., and Polissou, M. 2007. "Investigation of the Antioxydant Properties of Ferula Orientalis L Using a Suitable Extraction Procedure.” Food Chemistry 100: 584-9.

[16] Kristakis, A. K. 1998. Composition of Olive Oil. USA: Food and Nutrition Press, 113-54.

[17] Djeridane, A., Yous, M., Nadjemi, B., Boutassouna, D., Stocker, P., and Vidal, N. 2006. “Antioxidant Activity of Some Algerian Medical Plants Extracts Containing Phenolic Compounds.” Food Chem. 97: 654-60.

[18] Lazzer, A., Cossentini, M., Khlif, M., and Karray, B. 2006. “Etude de l'évolution des stérols, des alcools aliphatiques et des pigments de l'huile d'olive au cours du processus de maturation.” Journal de la société chimique de Tunisie 8: 21-32.

[19] Salvador, M. D., Aranda, F., Gomez Alonso, S., and Fregapane, G. 2001. "Cornicabra Virgin Olive Oil: A Study of Five Crop Seasons. Composition, Quality and Oxidative Stability.” Food Chemistry 74: 267-74.

[20] Kalua, C. M., Allen, M. S., Bedgood Jr, D. R., Bishop, A. G., Prenzler, P. D., and Robards, K. 2007. "Olive Oil Volatile Compounds, Flavour Development and Quality: A Critical Review.” Food Chemistry 100: 273-86.

[21] Baros, B., Jakabova, S., Dornyei, A., Horvath, J., and Kimar, F. 2010. "Determination of Polyphenolic Componds by Liquid Chromatography Mass Spectrometry.” Journal of Chromatography 1217.

[22] Alessandra, B., Lorenzo, C., Alegria, C. P., Ana Maria, G. C., Antonio Segura-C., Alberto, F. G., and Giovanni, L. 2007. "Phenolic Molecules in Virgin Olive Oils: A Survey of Their Sensory Properties, Health Effects, Antioxidant Activity and Analytical Methods." Molecules 12: 
1679-719.

[23] Douzane, M., Tamendjari, A., Abdi, A. K., Daas, M.S., Mehdid, F., and Bellal, M. M. 2013. "Phenolic Compounds in Mono-cultivar Extra Virgin Olive Oils from Algeria." Grasas and Aceites 64 (3): 285-94.

[24] Brenes, M., Hidalgo, F. J., Garcia, A., Rios, J. J., Garcia, P., Zamora, R., and Garrido, A. 2000. "Pinoresinol and 1-Acetoxy Pinoresinol, Two New Phenolic Compounds Identified in Olive Oil." Journal of American Oil
Chemist's Society 77 (7): 715-20.

[25] Brenes, M., Garcia, A., Garcia, P., Rios, J. J., and Garrido, A. 1999. "Phenolic Compounds in Spanish Olive Oils.” Journal of Agricultural and Food Chemistry 47 (9): 3535-40.

[26] Brenes, M., Garcia, A., Rios, J. J., Garcia, P., and Garrido, A. 2002. "Use of 1-Acetoxy Pinoresinol to Authenticate Picual Olive Oils.” The International Journal of Food Science and Technology 37 (6): 615-25. 